\section{Potassium Application and Leaf Sufficiency Level for Fresh-market Tomatoes Grown on a Midwestern United States Fine-textured Soil}

\author{
H.G. Taber ${ }^{1}$
}

\begin{abstract}
AdDitional INDEX wORDs. leaf $\mathrm{K}$, sap $\mathrm{K}$, plant analysis
Summary. Tomato (Lycopersicon esculentum) response to potassium (K) fertilization on a well-drained, central Iowa loam soil testing low in exchangeable $\mathrm{K}$ was evaluated over a 3-year period. Each year the experimental design was a factorial, split-plot randomized complete block with $\mathrm{K}$ rate as the whole unit ( 0 to $332 \mathrm{lb} / \mathrm{acre}$ ). The subunit was cultivar, either 'Mountain Spring' (determinate growth habit) or 'Jet Star' (indeterminate growth habit). Fruit harvest began the first week of August and continued weekly for $\mathbf{5}$ to 8 weeks. For all years there was a significant $\mathrm{K}$ rate and cultivar effect for all parameters, but no interaction except for marketable fruit size and unmarketable fruit produced. Increasing the $\mathrm{K}$ rate to $103 \mathrm{lb} /$ acre increased fruit size of both cultivars to a maximum of $8.9 \mathrm{oz}$, but year accounted for greater fruit size difference than the choice of cultivar. Maximum marketable yield for both cultivars occurred at $220 \mathrm{lb} /$ acre K with 'Jet Star' producing 13\% more fruit than 'Mountain Spring', 359 vs. 319 $\mathrm{cwt} / \mathrm{acre}$, respectively. Cullage was high, mostly as a result of blotchy ripening disorders, with 'Jet Star' consistently producing more culls than 'Mountain Spring'. Increasing $\mathrm{K}$ rate did not reduce the percentage of culls, which remained constant at about $29 \%$ of total yield. Whole-leaf $K$ and leaf petiole sap $K$ levels linearly increased with additional $\mathrm{K}$ rate for the two sample periods at flowering and mid-harvest. The whole-leaf $\mathrm{K}$ sufficiency level for both cultivars at the flowering stage of growth was determined to be $3.15 \%$ and dropped to $1.30 \% \mathrm{~K}$ by mid-harvest. Critical petiole leaf sap K values (using a dilution of $1: 1$ sap to water) could not be determined at flowering, but at mid-harvest the critical value was about 2200 to $2800 \mathrm{ppm} \mathrm{K}$.
\end{abstract}

$\mathrm{P}$ otassium fertilizer recommendations and plant analysis $\mathrm{K}$ sufficiency ranges for fresh-market tomatoes have been established in several regions of the United States. In the midwestern U.S., the tomato soil $\mathrm{K}$ recommendation ranges from 200 to $300 \mathrm{lb} /$ acre $\mathrm{K}$, depending on the exchangeable $\mathrm{K}$ soil test level as determined by ammonium acetate or Mehlich No. 3 extraction methodology, for the north-central region of the U.S. (Brown, 1998). Only Michigan recommends $\mathrm{K}$ be added to soils testing in the high range (Warncke et al., 1992). In Iowa, long-term K applications to fine-textured soils have increased the exchangeable K to a level where corn (Zea mays) and soybean (Glycine max) no longer respond to additional Kapplications (Mallarino et al., 1991). Tomatoes are often grown

${ }^{1}$ Professor and Extension Vegetable Specialist, Department of Horticulture, Iowa State University, Ames, IA 50011. E-mail: taber@iastate.edu

My thanks to Diane Shogren, Horticulture Department, for technical field and laboratory support, and to Dr. Phillip Dixon, Department of Statistics, for assistance with the analysis presentation. in a general crop rotation of corn, soybean, meadow where the soil $\mathrm{K}$ level may be adequate for the agronomic crop but deficient for tomatoes. With deficient soil $\mathrm{K}$ conditions, not only will yields be lower, but the tomato fruit will be small, drop from the plant prematurely, and lack red color (poor lycopene development), which leads to blotchy ripening (Dangler and Locascio, 1990; Hartz et al., 1999; Widders and Lorenz, 1979; Wilcox, 1993). Blotchy ripening is the result of uneven coloring, external and internal, with typical symptoms of yellow shoulders and white, internal tissue. The condition is a common but unpredictable problem, and it is often severe enough to render the fruit unsuitable for market (Pica, 1987). Soil $\mathrm{K}$ additions above those needed for high yields may reduce fruit color disorders (Hartz et al., 1999).

Potassium is often applied by commercial vegetable growers at $>125$ $\mathrm{lb} / \mathrm{acre}$ to soils with a high exchangeable K soil test, and some growers may use as much as twice the recommended rate. Part of the reason for the high application is for insurance against yield loss and fruit quality disorders, and the fact that tomatoes require a high amount of $\mathrm{K}$ compared to most other vegetable crops, field corn, and soybean. The amount of $\mathrm{K}$ in each ton of fruit varies from 5 to $6.6 \mathrm{lb} /$ ton (Gould, 1992). Thus, an average 30ton crop would remove $203 \mathrm{lb} \mathrm{K}$ in the fruit alone.

Plant analysis is a good tool for monitoring and appraising tomato plant Kstatus and adjusting fertilizer $\mathrm{K}$ rates based on soil test values. To be effective, reliable plant sufficiency ranges have to be established for a specific crop growth stage, as the vegetative tissue $\mathrm{K}$ concentration declines with increasing plant maturity (Locascio et al., 1997; Widders and Lorenz, 1979; Wilcox, 1993). Both total whole-leaf (blade + petiole) K concentration, expressed as percentage on a dry weight basis, and the $\mathrm{K}$ fraction in the petiole sap, expressed on a fresh weight basis as parts per million, have been used successfully to obtain these data (Hochmuth, 1994). The youngest, most recently matured leaf, which is generally the fourth or fifth leaf from the growing point, is accepted as the sample unit for both procedures.

The leaf $\mathrm{K}$ sufficiency range for

\begin{tabular}{llll}
\hline $\begin{array}{l}\text { Units } \\
\begin{array}{l}\text { To convert U.S. to SI, } \\
\text { multiply by }\end{array}\end{array}$ & U.S. unit & SI unit & $\begin{array}{l}\text { To convert SI to U.S., } \\
\text { multiply by }\end{array}$ \\
\hline $\mathrm{l}$ & $\mathrm{cbar}$ & $\mathrm{kPa}$ & $\mathrm{l}$ \\
112.0851 & $\mathrm{cwt} / \mathrm{acre}$ & $\mathrm{kg} \cdot \mathrm{ha}^{-1}$ & 0.0089 \\
0.3048 & $\mathrm{ft}$ & $\mathrm{m}$ & 3.2808 \\
3.7854 & $\mathrm{gal}$ & $\mathrm{L}$ & 0.2642 \\
2.54 & inch(es) & $\mathrm{cm}$ & 0.3937 \\
25.4 & inch $(\mathrm{es})$ & $\mathrm{mm}$ & 0.0394 \\
0.4536 & $\mathrm{lb}$ & $\mathrm{kg}$ & 2.2046 \\
1.1209 & $\mathrm{lb} / \mathrm{acre}$ & $\mathrm{kg} \cdot \mathrm{ha}^{-1}$ & 0.8922 \\
0.5 & $\mathrm{lb} / \mathrm{ton}$ & $\mathrm{kg} \cdot \mathrm{Mg}^{-1}$ & 2 \\
28.3495 & $\mathrm{oz}$ & $\mathrm{g}$ & 0.0353 \\
1 & $\mathrm{ppm}$ & $\mathrm{mg} \cdot \mathrm{kg}^{-1}$ & 1 \\
0.9072 & ton $(\mathrm{s})$ & $\mathrm{Mg}$ & 1.1023 \\
$\left({ }^{\circ} \mathrm{F}-32\right) \div 1.8$ & ${ }^{\circ} \mathrm{F}$ & ${ }^{\circ} \mathrm{C}$ & $\left(1.8 \times{ }^{\circ} \mathrm{C}\right)+32$ \\
& & &
\end{tabular}


optimum yield and fruit quality has been investigated extensively. Mills and Jones (1996), after an extensive review of the literature, suggested a tomato whole-leaf $\mathrm{K}$ sufficiency range at mid-bloom period of growth of $2.5 \%$ to $5.0 \%$. Wilcox (1993) conducted research on the fine-textured silt loam soils of Indiana and considered the whole-leaf K sufficiency range at flowering and fruit formation to be $2.5 \%$ to $4.0 \%$. Lorenz and Tyler (1983), in research on the fine-textured soils in California, found the sufficiency range to be $2.5 \%$ to $4.0 \%$ at flowering and declined to $1.5 \%$ to $3.0 \%$ at first ripe fruit as the fruit became the principal sink for K. However, recent California work showed that high yields of the newer, strongly determinate processing-type tomato can be maintained with leaf K concentration at full bloom of only $1.6 \%$ to $3.0 \%$ (Hartz et al., 1998). Extensive Florida research on sandy soils with fresh-market, mulched bed, staked tomato indicated a higher sufficiency range at $3.5 \%$ to $4.0 \%$ at first flower, and gradually decreased throughout the growing season to $2 \%$ to $3 \%$ by mid-harvest (Hochmuth, 1994). The corresponding petiole $\mathrm{K}$ sap values were 3500 to $4000 \mathrm{ppm}$ at first open flowers and dropped to 2000 to $2500 \mathrm{ppm}$ by second harvest.

The objectives of this project were to: 1 ) determine the optimum fertilizer $\mathrm{K}$ application rate for high yield and fruit quality of the standard indeterminate and determinate fresh-market tomato cultivars grown on a typical midwestern U.S. prairie soil; and 2) determine the whole-leaf K sufficiency values, and corresponding leaf petiole sap concentrations.

\section{Materials and methods}

Six-week-old tomato greenhouse transplants, raised in 72-cell plastic trays, were transplanted to field plots at the Horticulture Station, Ames, Iowa, on 20 May 1998, 25 May 1999, and 18 May 2001. The culture system included black polyethylene mulch with a singleline-source drip irrigation system (16$\mathrm{mm}$ tubing, 12-inch emitter spacing, $0.53 \mathrm{gal} / \mathrm{h}$; Drip-In Irrigation Co., Fresno, Calif.) that produced a wetted radius of 16 inches. The previous crop rotational scheme was meadow, cereal rye (Secale cereale), and buckwheat (Fagopyrum esculentum). The soil type was a well-drained, central Iowa loam (prairie developed on glacial till, fine- loamy, mixed, mesic Typic Hapudoll) with $2.4 \%$ organic matter, 13.1 cation exchange capacity (CEC), and a water $\mathrm{pH}$ of 6.8 (Brown, 1998). Irrigation was applied uniformly to all plots from a collection pond to maintain 8 -inch-depth tensiometer (Irrometer Co., Riverside, Calif.) readings at $30-35 \mathrm{kPa}$.

The soil test level of $89 \mathrm{ppm} \mathrm{K}$ determined by Mehlich No. 3 methodology (Brown, 1998) was considered very low for field corn and soybean production, and would require 108 $\mathrm{lb} /$ acre $\mathrm{K}$ for optimum corn yield (Sawyer et al., 2002). The experimental design was a factorial, split-plot, randomized complete-block design with four replications. The whole unit was six $\mathrm{K}$ rates $(0,20.8,41.5,83,166$, and $332 \mathrm{lb} /$ acre as $0 \mathrm{~N}-0 \mathrm{P}-51.5 \mathrm{~K}$ in the form of potassium chloride). Onehalf of the $\mathrm{K}$ fertilizer was broadcast uniformly over the entire plot area the previous fall (October or November) and plowed down (moldboard), and the remainder applied broadcast and incorporated (rotovated 8 -inch depth) along with $75 \mathrm{lb} /$ acre nitrogen $(\mathrm{N})$, $65 \mathrm{lb} /$ acre phosphorus $(\mathrm{P})$, and the herbicide trifluralin (Treflan; Dow AgroSciences LLC, Indianapolis) just prior to laying the 4 -ft-wide black polyethylene film on 6-ft row centers. The mulch film was laid flat without a bed shaper. No fertilizer was applied through the drip system. The subunit was cultivar, either 'Mountain Spring' (determinate growth habit) or 'Jet Star' (indeterminate growth habit), the major fresh-market commercial tomato cultivars. Each K level main plot was four rows wide and $30 \mathrm{ft}$ long. The cultivar treatments consisted of a single inner row with plant in-row spacing of 18 inches. Plants were staked, pruned once to the first flower cluster, and tied following the Florida stake and weave system (Konsler and Gardner, 1990). There were four ties for the determinate 'Mountain Spring' and six ties for the indeterminate 'Jet Star'. Normal pest management practices for the area were followed.

Leaf samples were taken at the flowering-vegetative (late June to mid-July) and mid-harvest stages of growth for whole-leaf $\mathrm{K}$ and petiole sap $\mathrm{K}$ analysis. Twelve most recently matured leaves were collected between 0900 and 1100 Hr from each treatment plot. Six whole leaves (leaflet blade + petiole) were randomly selected from the group and dried in a forced-air oven for $72 \mathrm{~h}$ at $67^{\circ} \mathrm{C}$ and then ground to pass a $1-\mathrm{mm}$ screen using a Wiley mill. Leaf total $\mathrm{K}$ was determined by dry ashing, taking up the ash in 1 $\mathrm{N}$ aqua regia (one part $15 \mathrm{~m}(70 \%)$ nitric acid to three parts $12 \mathrm{~m}(36 \%)$ hydrochloric acid), and measuring $\mathrm{K}$, calcium $(\mathrm{Ca})$, and magnesium $(\mathrm{Mg})$ in the solution by inductive coupled plasma (ICP) techniques (Soltanpour et al., 1996). The remaining six leaves were stripped of the leaflet blades for petiole K sap analysis. The sampled petioles were placed on ice, transported to the laboratory and frozen at $-10{ }^{\circ} \mathrm{C}$ until analysis within 1 to 4 weeks. Thawed petioles were cut into pieces and the sap extracted with a hand-held garlic press. For 1999 and 2001, sap was diluted (1:1) with distilled water and $\mathrm{K}$ measured with a calibrated Cardy flat electrode (Horbia Instruments Ltd., Kyoto, Japan) and by standard ICP techniques. Sap was not diluted in 1998 and was not used in the analysis.

Fruit harvest began when 10\% of the fruit were at the breaker-stage, generally the first week of August. All fruit showing color were harvested once per week and harvest continued for 5 to 8 weeks, depending on the year. Yield data included overall fruit size and weight of marketable and cull fruit. Culls included small fruit $(<2$ $1 / 4$ inches diameter) and fruit with rots, radial and concentric cracks, and blotchy ripening over more than $5 \%$ of the fruit surface.

Data were statistically analyzed as a split-split plot with years $(3)$ as the whole unit, $\mathrm{K}$ rate (6) as a sub-unit, and cultivar (2) as a sub-sub unit. The SAS routines of MIXED, REG, and NLIN were used where appropriate (version 8e; SAS Institute, Cary, N.C.). The Cate-Nelson split (Cate and Nelson, 1971) was used to examine the relationship between whole-leaf $\mathrm{K}$ concentration, or leaf petiole sap $\mathrm{K}$ concentration, and relative marketable yield (RMY). The data were split into two groups by setting the horizontal line at 95\% RMY. Relative yield was calculated as the yield obtained for a given $\mathrm{K}$ rate averaged across the two cultivars and expressed as a percentage of the yield observed for the highest $\mathrm{K}$ rate within each year. The critical value was determined by the intersection of the horizontal and vertical lines. The vertical line was drawn to maximize the 
number of observations in the lower left quadrant (deficient) and the upper right quadrant (sufficient).

\section{Results and discussion}

YIELD. Marketable yield was similar all 3 years with significant $(P<$ 0.01 ) effects of Krate and cultivar (Fig. 1). Of the mathematical models tested (linear, quadratic, linear-plateau, and quadratic-plateau) the linear-plateau model best described the $\mathrm{K}$ rate relationship to marketable yield $\left(r^{2}=0.38\right)$. At the optimum K rate of $220 \mathrm{lb} /$ acre $\mathrm{K}$, the indeterminate 'Jet Star' produced $13 \%$ more marketable fruit than the determinate 'Mountain Spring', 359vs. $319 \mathrm{cwt} /$ acre, respectively. Marketable fruit size obtained depended on the year and cultivar, but Krate was independent of year or cultivar $(P<0.0001)$ (Table $1)$. The cultivar $\times$ year interaction indicated 'Jet Star' produced 1.0 oz larger fruit than 'Mountain Spring' in 1999; 'Mountain Spring' fruit was larger by $0.6 \mathrm{oz}$ in 2001; and the two cultivars similar in 1998. Year-to-year variation accounted for greater fruit size difference than cultivar choice within a year. Increasing the $\mathrm{K}$ rate to $103 \mathrm{lb} /$ acre achieved maximum fruit size of both cultivars.

Cull yield was affected by a year $x$ cultivar interaction (Table 2 ). Culls were mostly blotchy ripening, a few misshapen, and radial cracks. 'Jet Star' produced 1.7 times more cull fruit in 1998 and 2001 than 'Mountain Spring', but there was no difference between the cultivars in 1999 when overall cull production was significantly less than in the other 2 years. Cullage was high for the 3-year period, with 'Mountain Spring' and 'Jet Star' producing $26 \%$ and $31 \%$ of total fruit, respectively. The growing season temperatures may partially explain the yearly differences. Year 1998 was hot and dry with an average temperature of $3.4^{\circ} \mathrm{F}$ above normal. Although the 2001 average growing season temperature was near normal, July and August were $1^{\circ} \mathrm{F}$ above normal with $20 \mathrm{~d}>90$ ${ }^{\circ} \mathrm{F}$. The 1999 seasonal temperature was $2^{\circ} \mathrm{F}$ below normal, although the month of July averaged $4^{\circ} \mathrm{F}$ above normal. High air temperatures and humidity during fruit lycopene formation has the greatest influence on blotchy ripening disorders (Pica, 1987). Interestingly, increasing the $\mathrm{K}$ application rate did not reduce the cull percentage (Table 2 ). The main effect of fertilizer K rate on cull yield was significant $(P<0.01)$ but difficult to explain without strong evidence for trend analysis. Potassium rates $>41.5 \mathrm{lb} /$ acre had little effect on cullage (Table 2 ).

WHOLE-LEAF K CONCENTRATION. Leaf $\mathrm{K}$ responded linearly to $\mathrm{K}$ application all years for both sampling times (Fig. 2). The year effect was not significant. Average leaf K concentration dropped from $2.81 \%$ to $1.24 \%$ between the two sampling periods (flowering to mid-harvest). There was no $\mathrm{K}$ rate $\times$ cultivar interaction for either sampling date. At the flowering and vegetative development stage of growth, 'Mountain Spring' plants contained a small, but significantly $(P<0.01)$ higher $\mathrm{K}$ concentration $(0.25 \%)$ than 'Jet Star'. By mid-harvest the situation was reversed, with 'Jet Star' leaves containing $0.16 \%$ more K than 'Mountain Spring' $(P=0.03)$. There can be a large difference in $\mathrm{K}$

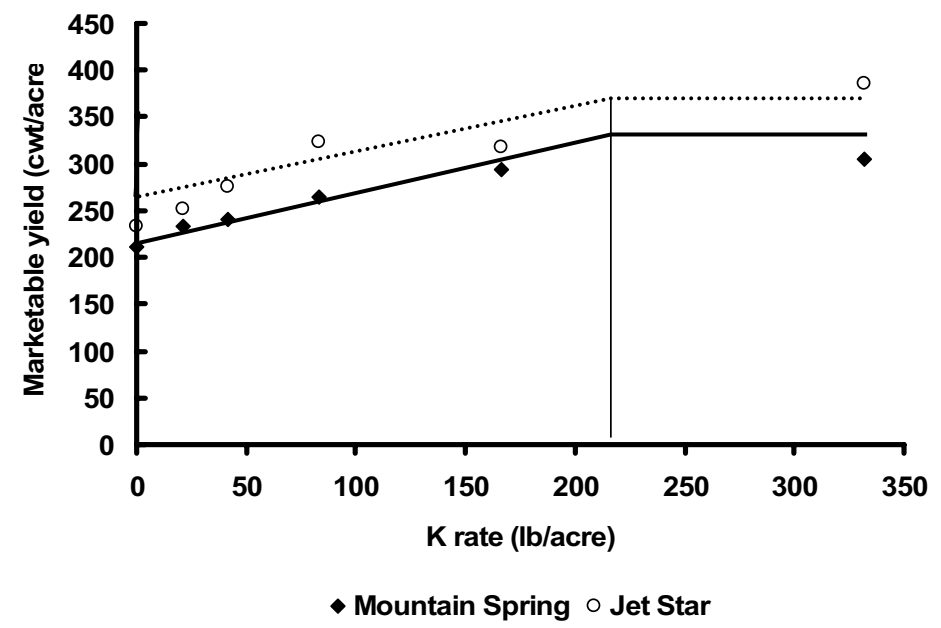

Fig. 1. Effect of fertilizer potassium (K) rate on marketable yield of fresh-market tomato cultivars, grown on a prairie loam soil, central Iowa, averaged over 1998, 1999, and 2001. Only the main effects of $\mathrm{K}$ rate and cultivar were significant. The linear-plateau model $\left(r^{2}=0.38\right)$ showed that the optimum $220 \mathrm{lb} /$ acre $\mathrm{K}$ rate resulted in $359 \mathrm{cwt} /$ acre for 'Jet Star' and $319 \mathrm{cwt} / \mathrm{acre}$ for 'Mountain Spring'. At K rates $\leq 220 \mathrm{lb} /$ acre, 'Jet Star' yield $=253+0.48 \mathrm{x}$ and 'Mountain Spring yield' $=213+0.48 \times\left(1 \mathrm{cwt} /\right.$ acre $=112.0851 \mathrm{~kg} \cdot \mathrm{ha}^{-1} ; 1 \mathrm{lb} /$ acre $=1.1209$ $\left.\mathrm{kg} \cdot \mathrm{ha}^{-1}\right)$.

Table 1. Effect of fertilizer potassium (K) application rate and tomato cultivar on marketable fruit size. Plants grown on a prairie loam soil in central Iowa.

\begin{tabular}{|c|c|c|c|}
\hline \multirow[b]{2}{*}{ Treatment } & \multicolumn{3}{|c|}{ Production year } \\
\hline & 1998 & 1999 & 2001 \\
\hline & \multicolumn{3}{|c|}{---- Fruit wt $[\text { mean } \pm S E(o z / \text { fruit })]^{\mathrm{z}}$} \\
\hline \multicolumn{4}{|c|}{ 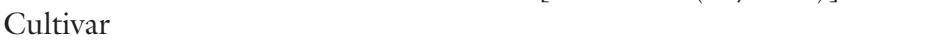 } \\
\hline Mountain Spring & $6.8 \pm 0.22$ & $7.6 \pm 0.19$ & $9.5 \pm 0.19$ \\
\hline Jet Star & $7.0 \pm 0.22$ & $8.6 \pm 0.19$ & $8.9 \pm 0.19$ \\
\hline$P$ & --_- & $--<0.001--$ & - n \\
\hline $\mathrm{K}(\mathrm{lb} / \mathrm{acre})^{\mathrm{y}}$ & \multicolumn{3}{|c|}{---- Fruit wt (oz/fruit $)^{x}----$} \\
\hline 0 & \multicolumn{3}{|c|}{7.0} \\
\hline 20.8 & \multicolumn{3}{|c|}{7.7} \\
\hline 41.5 & \multicolumn{3}{|c|}{7.9} \\
\hline 83.0 & \multicolumn{3}{|c|}{8.4} \\
\hline 166.0 & \multicolumn{3}{|c|}{8.7} \\
\hline 332.0 & \multicolumn{3}{|c|}{8.8} \\
\hline SE & \multicolumn{3}{|c|}{0.2} \\
\hline
\end{tabular}

${ }^{\mathrm{z}} \mathrm{loz}=28.3495 \mathrm{~g}$.

yne-half broadcast uniformly over the whole plot area the previous fall and plowed down and the remainder in the spring just prior to rotovation and laying the black polyethylene mulch $\left(1 \mathrm{lb} /\right.$ acre $\left.=1.1209 \mathrm{~kg} \cdot \mathrm{ha}^{-1}\right)$.

${ }^{x}$ Mean across cultivar and year, as only the main effect of K rate was significant. The relationship of $\mathrm{K}$ rate and marketable fruit weight is a linear-plateau with maximum fruit weight achieved at $103 \mathrm{lb} /$ acre $\mathrm{K}\left(\mathrm{Y}=7.2+0.0178 \mathrm{x}, r^{2}=0.25\right)$. 
Table 2. Effect of fertilizer potassium (K) application rate and tomato cultivar on cull fruit production. Plants grown on a prairie loam soil, central Iowa.

\begin{tabular}{|c|c|c|}
\hline \multirow[b]{2}{*}{ Treatment } & \multicolumn{2}{|c|}{ Production year } \\
\hline & 1999 & 2001 \\
\hline & ---- Culls $[$ mean \pm SE $(\mathrm{cu}$ & wt/acre) $]^{\mathrm{z}}-\cdots-$ \\
\hline \multicolumn{3}{|c|}{ 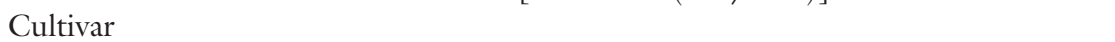 } \\
\hline Mountain Spring & $96 \pm 6.6$ & $91 \pm 5.6$ \\
\hline Jet Star & $154 \pm 6.6$ & $168 \pm 5.6$ \\
\hline$P$ & $-1-1001-$ & - \\
\hline $\mathrm{K}(\mathrm{lb} / \mathrm{acre})^{\mathrm{y}}$ & ---- Culls (cwt/acre $)^{x}---$ & --.-- Culls (\% total yield) --.- \\
\hline 0 & 89 & 28.5 \\
\hline 20.8 & 99 & 29.0 \\
\hline 41.5 & 117 & 31.1 \\
\hline 83.0 & 119 & 28.3 \\
\hline 166.0 & 119 & 27.1 \\
\hline 332.0 & 137 & 28.3 \\
\hline SE & 2.4 & NS \\
\hline
\end{tabular}

${ }^{2} \mathrm{NS}=$ nonsignificant $\left(\mathrm{l} \mathrm{cwt} / \mathrm{acre}=112.0851 \mathrm{~kg} \cdot \mathrm{ha}^{-1}\right)$.

yone-half broadcast uniformly over the whole plot area the previous fall and plowed down and the remainder in the spring just prior to rotovation and laying the black polyethylene mulch $\left(1 \mathrm{lb} / \mathrm{acre}=1.1209 \mathrm{~kg} \cdot \mathrm{ha}^{-1}\right)$. "Mean across cultivar and year, as the only main effect of $\mathrm{K}$ rate was significant. The linear-plateau relationship between $\mathrm{K}$ rate and cull yield: $\mathrm{Y}=99+0.129 \mathrm{x}, \mathrm{x} \leq 294, \mathrm{r}^{2}=0.08$.
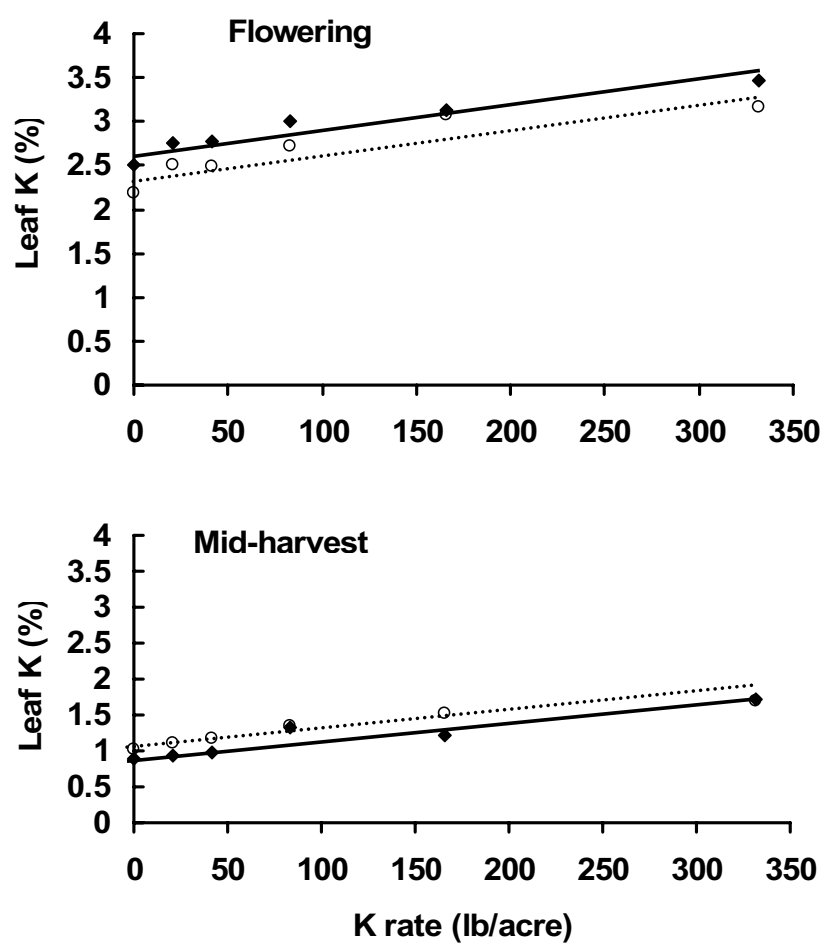

○ Jet Star • Mountain Spring

Fig. 2. Whole-leaf potassium $(K)$ concentration (\% dry weight) as affected by fertilizer $\mathrm{K}$ rate for two tomato cultivars. Values averaged across 3 years $(\mathrm{n}=144)$. Flowering stage was 11 July 1998, 6 July 1999, and 28 June 2001. Harvest began on 11 Aug. 1998, 5 Aug. 1999, and 10 Aug. 2001. Linear response $\left(r^{2}\right.$ $=0.43$ ) at flowering: 'Jet Star' leaf $\mathrm{K}=2.41+0.0027 \mathrm{x}$; 'Mountain Spring' leaf $K=2.66+0.0027 x$. At mid-harvest time period $\left(r^{2}=0.28\right)$ : 'Jet Star' leaf $K=$ $1.08+0.0022 x$; 'Mountain Spring' leaf $K=0.94+0.0022 x(1 \mathrm{lb} /$ acre $=1.1209$ $\left.\mathrm{kg} \cdot \mathrm{ha}^{-1}\right)$. accumulation between indeterminate and determinate tomato types based primarily on root growth differences (Widders and Lorenz, 1979). During the fruit ripening period the leaf $\mathrm{K}$ concentration will be lower for the determinate types ('Mountain Spring'), as compared to indeterminate cultivars ('Jet Star'), because of heavy fruit set requiring large $\mathrm{K}$ translocation out of the leaves. The smaller root system of the determinate types cannot meet the high fruit demand. However, in this study there were not large leaf $\mathrm{K}$ concentration differences between the two cultivars. The lack of difference in $\mathrm{K}$ accumulation may be related to the alteration of the usual root growth pattern of the two cultivars. Black polyethylene mulch and drip irrigation promotes extensive lateral root growth in the upper soil profile zone so the root absorption surfaces may have been similar (Gough, 2001; Wein et al., 1993).

At the flowering and mid-harvest sampling dates, whole-leaf $\mathrm{K}$ concentration was significantly $(P<0.01)$ correlated to yield $(r=0.79$ for both dates). Therefore, whole-leaf $\mathrm{K}$ concentration may be used as a measure of adequate fertilization. Because of the small-leaf $\mathrm{K}$ concentration difference between cultivars, the values were averaged to determine critical deficiency levels. Maximum marketable yield for both cultivars occurred at 220 $\mathrm{lb} /$ acre K application rate; so the leaf $\mathrm{K}$ concentration at this rate could be used to approximate the K sufficiency level. For 'Mountain Spring' and 'Jet Star' that value should be $>3.00 \% \mathrm{Kap}$ proximately 4-5 weeks after transplanting (period of flowering and vegetative development). Using the Cate-Nelson graphing procedure (Cate and Nelson, 1971) the corresponding whole-leaf sufficiency level would be $3.15 \%$ to obtain relative yields of $95 \%$ (Fig. $3)$. The corresponding value for the mid-harvest period would be $1.30 \%$. These levels are below the established Florida sufficiency range of $3.5 \%$ to $4.0 \%$ at first flower and $2.0 \%$ to $2.5 \%$ by the second harvest for fresh-market tomatoes grown on sandy soils with a similar intensive culture system ( $\mathrm{Ho}^{-}$ chmuth, 1994). However, they are within the broader sufficiency range of $2.5 \%$ to $4.0 \%$ at flowering established in Califlornia (Lorenz and Tyler, 1983) and Indiana (Wilcox, 1993) with plants grown on fine-textured soils. 

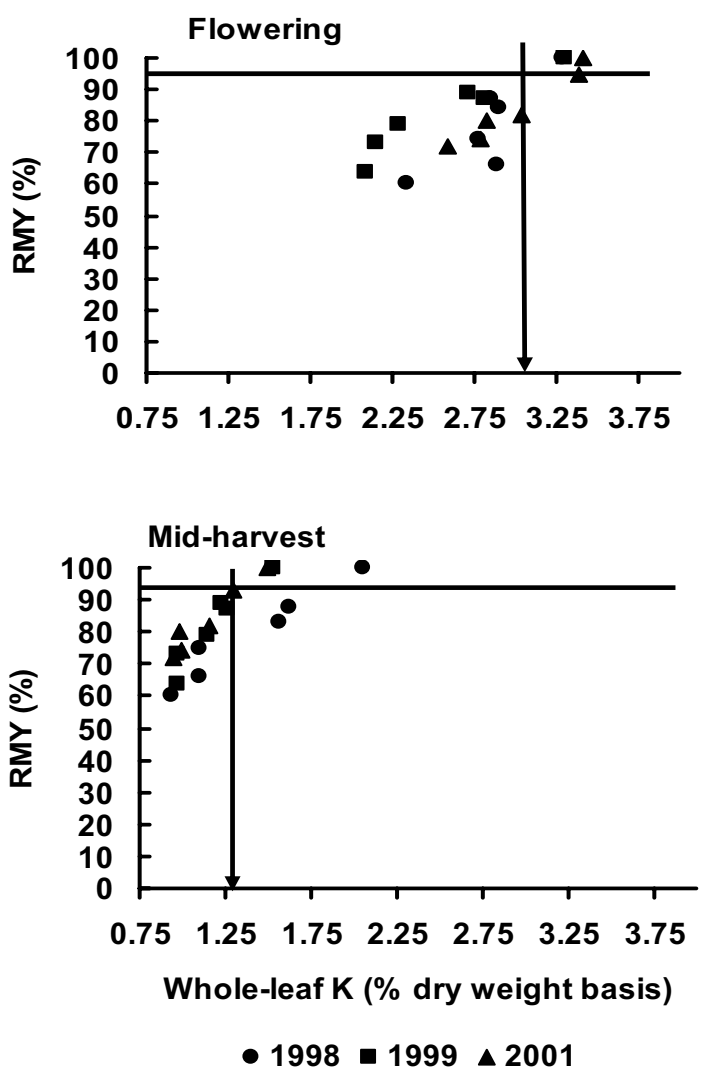

Fig. 3. Relationship between tomato whole-leaf potassium (K) concentration and relative marketable yield (RMY) for two plant sampling times over 3 years. Each point is the mean of two cultivars for each $K$ rate for each year. Data were partitioned (vertical line) as sufficient (upper right quadrant) and deficient (lower left quadrant) at $\mathbf{9 5 \%}$ RMY with the Cate-Nelson graphic procedure.

It is well known that high Klevels may negatively impact plant $\mathrm{Ca}$ and $\mathrm{Mg}$ content. This study found minor, but significant, effects of increasing the soil $\mathrm{K}$ rate on whole-leaf $\mathrm{Ca}$ and $\mathrm{Mg}$ concentrations at the flowering sample time. However, leaf $\mathrm{Ca}$ and $\mathrm{Mg}$ concentrations, as well as all other essential nutrients, were within sufficiency guidelines for all $\mathrm{K}$ treatments (Mills and Jones, 1996).

Petiole sap K concentration. A more rapid, real-time procedure to measure $\mathrm{K}$ status is to measure $\mathrm{K}$ in the petiole sap. Leaf petiole sap $\mathrm{K}$ concentration was measured on diluted sap to avoid the non-linear response with the Cardy electrode above K concentrations of $3000 \mathrm{ppm} \mathrm{K}$ (Rosen et al., 1996). Both ICP and the flat electrode Cardy meter techniques were used for sampling dates in years 1999 and 2001 when diluted sap was available. The correlation between the two methods was $r=0.92$ (data not
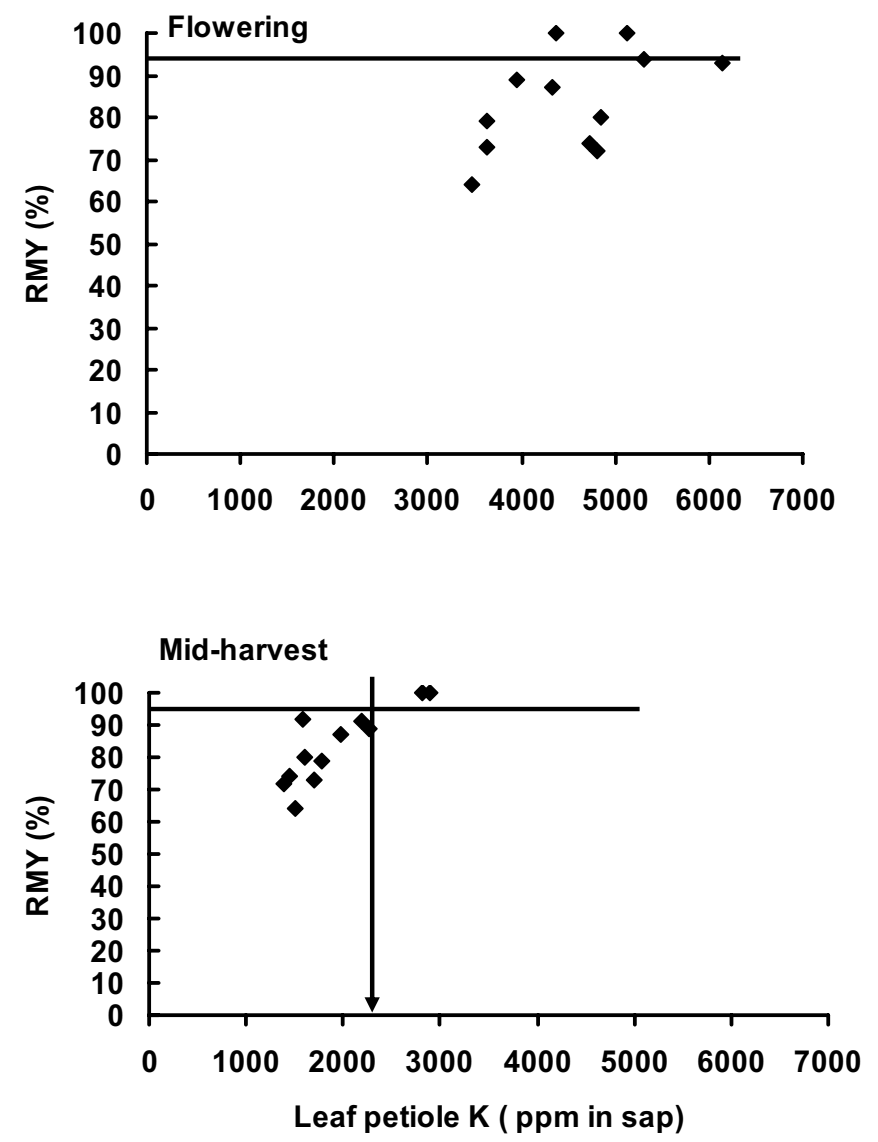

Fig. 4. Relationship between tomato petiole sap potassium (K) concentration and relative marketable yield RMY) for two sampling times for 1999 and 2001. Each value is the mean of two cultivars and 2 years for each $\mathrm{K}$ rate. Data were partitioned (vertical line) as sufficient (upper right quadrant) and deficient (lower left quadrant) at $95 \% \mathrm{RMY}$ with the Cate-Nelson graphic procedure $\left(1 \mathrm{ppm}=1 \mathrm{mg} \cdot \mathrm{kg}^{-1}\right)$.

presented). Petiole sap Kconcentration was correlated to whole-leaf $\mathrm{K}$ at $\mathrm{r}=$ 0.68 and $0.73(n=96)$ for flowering and mid-harvest sampling periods, respectively. These correlations are similar to other studies with tomato (Locascio et al., 1997). With eggplant (Solanum melongena), Hochmuth et al. (1993) found a high correlation, $r=$ 0.83 , between petiole sap Kand wholeleaf Kacross five sampling dates. Using the Cate-Nelson graphing procedure as before, the petiole sap $\mathrm{K}$ critical value between deficient and sufficient at flowering stage of growth could not be determined because of high variability in the data (Fig. 4). However, at the mid-harvest time period sufficiency level sap K values were about 2200 to $2800 \mathrm{ppm} \mathrm{K}$, which is very similar to Florida and California values (Hartz and Hochmuth, 1996).

\section{Conclusions}

On Iowa soils with a low or very low exchangeable Ksoil test reading, as much as $220 \mathrm{lb} /$ acre K was necessary to optimize yield for a determinate and an indeterminate fresh-market tomato cultivar. Fertilizing for high yield maximized fruit size. Monitoring the crop $\mathrm{K}$ status via whole-leaf $\mathrm{K}$ during the growing season or petiole sap $\mathrm{K}$ concentration during harvest is an effective fertilizer management tool. For the intensive culture system of black polyethylene mulch, drip irrigation, pruned, and staked tomatoes, the sufficiency whole-leaf $\mathrm{K}$ level at the flowering stage of growth should be $\geq 3.15 \%$ and the petiole sap values (measured on diluted sap) at mid-harvest should be about 2200 to $2800 \mathrm{ppm}$. 


\section{Literature cited}

Brown, J.R. 1998. Recommended chemical soil test procedures for the North Central Region. NCR Res. Publ. No. 221., Univ. of Missouri, Columbia.

Cate, R.B. and L.A. Nelson. 1971. A simple statistical procedure for partitioning soil test correlation data into two classes. J. Soil Sci. Soc. Amer. 35:658-660.

Dangler, J.M. and S.J. Locascio. 1990. External and internal blotchy ripening and fruit elemental content of trickle-irrigated tomatoes as affected by $\mathrm{N}$ and $\mathrm{K}$ application time. J. Amer. Soc. Hort. Sci. 115:547-549.

Gough, R.E. 2001. Color of plastic mulch affects lateral root development but not root system architecture in pepper. HortScience 36:66-68.

Gould, W.A. 1992. Tomato production, processing, and technology. CTI Publ., Baltimore, $\mathrm{Md}$.

Hartz, T.K. and G.J. Hochmuth. 1996. Fertility management of drip-irrigated vegetables. HortTechnology 6:168-172.

Hartz, T.K., E.M. Miyao, and J.G. Valencia. 1998. DRIS evaluation of the nutritional status of processing tomato. HortScience $33: 830-832$.

Hartz, T.K., G. Miyao, R.J. Mullen, M.D. Cahn, J. Valencia, and K.L. Brittan. 1999. Potassium requirements for maximum yield and fruit quality of processing tomato. J. Amer. Soc. Hort. Sci. 124:199-204.
Hochmuth, G.J. 1994. Efficiency ranges for nitrate-nitrogen and potassium for vegetable petiole sap quick tests. HortTechnology 4:218-222.

Hochmuth, G.J., R.C. Hochmuth, M.E. Donley, and E.A. Hanlon. 1993. Eggplant yield in response to potassium fertilization on sandy soil. HortScience 28:1002-1005.

Konsler, T.K. and R.G. Gardner. 1990. Commercial production of staked tomatoes in North Carolina. N.C. State Univ. Agr. Ext. Serv. Publ. AG-405.

Locascio, S.J., G.J. Hochmuth, F.M. Rhoads, S.M. Olson, A.G. Smajstrla, and E.A. Hanlon. 1997. Nitrogen and potassium application scheduling effects on drip-irrigated tomato yield and leaf tissue analysis. HortScience 32:230-235.

Lorenz, O.A. and K.B. Tyler. 1983. Plant tissue analysis of vegetable crops, p. 24-29. In: H.M. Reisenauer (ed.). Soil and plant tissue testing in California. Univ. Calif. Bul. 1879.

Mallarino, A.P., J.R. Webb, and A.M. Blackmer. 1991. Corn and soybean yields during 11 years of phosphorus and potassium fertilization on a high-testing soil. J. Production Agr. 4:312-317.

Mills, H.A. and J.B. Jones, Jr. 1996. Plant analysis handbook 11. Micromacro Publ., Athens, Ga.

Pica, D.H. 1987. Physiological factors associated with yellow shoulder expression in tomato fruit. J. Amer. Soc. Hort. Sci. 112:798-801.
Rosen, C.J., M. Errebhi, and W. Wand. 1996. Testing petiole sap for nitrate and potassium: A comparison of several analytical procedures. HortScience 31:1173-1176.

Sawyer, J.E., A.P. Mallarino, R. Killorn, and S.K. Barnhart. 2002. A general guide for crop nutrient and limestone recommendations in Iowa. Iowa State Univ. Ext. Pm-1688.

Soltanpour, P.N., G.W. Johnson, S.M. Workman, J.B. Jones, Jr., and R.O. Miller. 1996. Inductively coupled plasma emission spectrometry and inductively coupled plasma-mass spectroscopy, p. 91-140. In: J.M. Bartels (ed.). Methods of soil analysis. Part 3. Chemical methods. Soil Sci. Soc. Amer., Amer. Soc. Agron., Madison, Wis.

Warncke, D.D., D.R. Christenson, L.W. Jacobs, M.L. Vitosh, and B.H. Zandstra. 1992. Fertilizer recommendations for vegetable crops. Mich. State Coop. Ext. Bul. E-550B.

Wein, H.C., P.L. Minotti, and V.P. Grubinger. 1993. Polyethylene mulch stimulates early root growth and nutrient uptake of transplanted tomatoes. J. Amer. Soc. Hort. Sci. 118:207-211.

Widders, I.E. and O.A. Lorenz. 1979. Tomato root development as related to potassium nutrition. J. Amer. Soc. Hort. Sci. 104:216-220.

Wilcox, G.E. 1993. Tomato, p. 137-141. In: W. F. Bennett (ed.). Nutrient deficiencies and toxicities in crop plants. APS Press, St. Paul, Minn. 